\title{
Recent patent applications in tissue engineering
}

\begin{tabular}{|c|c|c|c|c|c|}
\hline Patent \# & Subject & Assignee & Inventor(s) & $\begin{array}{l}\text { Priority } \\
\text { application } \\
\text { date }\end{array}$ & $\begin{array}{l}\text { Publication } \\
\text { date }\end{array}$ \\
\hline WO 200392760 & $\begin{array}{l}\text { A biocompatible, biodegradable composite carrier for tissue engineering } \\
\text { and implantation of bone material, comprising porous calcium phosphate } \\
\text { granules bonded by a biocompatible binder such as collagen. }\end{array}$ & $\begin{array}{l}\text { Merck Patent } \\
\text { (Darmstadt, } \\
\text { Germany) }\end{array}$ & $\begin{array}{l}\text { Jeschke B; } \\
\text { Nies B; } \\
\text { Schaffner P }\end{array}$ & $4 / 29 / 2002$ & $11 / 13 / 2003$ \\
\hline EP 1359214 & $\begin{array}{l}\text { A bioreactor comprising a grid and a portable outer housing enclosing } \\
\text { a sterile medium chamber in which an inner housing is disposed; } \\
\text { useful in receiving, maintaining or growing cells on a three-dimensional } \\
\text { biomaterial scaffold. }\end{array}$ & $\begin{array}{l}\text { IsoTis } \\
\text { (Bilthoven, } \\
\text { The Netherlands) }\end{array}$ & Oostra J & $5 / 3 / 2002$ & $11 / 5 / 2003$ \\
\hline WO 200388925 & $\begin{array}{l}\text { A method for the preparation of hydroxyapatite; useful for introducing } \\
\text { biomolecules into cells, for treating bone or tooth injury, and in tissue } \\
\text { engineering and repair. }\end{array}$ & $\begin{array}{l}\text { Carnegie Mellon } \\
\text { University } \\
\text { (Pittsburgh, } \\
\text { PA, USA) }\end{array}$ & $\begin{array}{l}\text { Campbell P, } \\
\text { Choi D, } \\
\text { Hollinger J, } \\
\text { Kumta PN, } \\
\text { Sfeir C, Weiss L }\end{array}$ & $4 / 18 / 2002$ & $10 / 30 / 2003$ \\
\hline WO 200388818 & $\begin{array}{l}\text { A monofilament or multifilaments with shape memory capability for } \\
\text { sutures, stents, catheters, prosthetics, grafts, screws, pins, pumps or } \\
\text { meshes. The shape memory polymer is capable of changing its shape } \\
\text { after an increase in temperature, enabling bulky implants to be placed } \\
\text { in the body through small incisions or to perform complex mechanical } \\
\text { deformations (e.g., knotting) automatically. }\end{array}$ & $\begin{array}{l}\text { Langer RS; } \\
\text { mnemoScience } \\
\text { (Aachen, Germany) }\end{array}$ & $\begin{array}{l}\text { Langer RS, } \\
\text { Lendlein A }\end{array}$ & 4/18/2002 & $10 / 30 / 2003$ \\
\hline WO 200377652 & $\begin{array}{l}\text { Use of a vascular endothelial growth factor for tissue engineering a } \\
\text { diabetic ulcer. The VEGF is administered for a sustained period of } \\
\text { time of at least two weeks to enhance the rate of closure of the wound } \\
\text { and reverse bacterial contamination. }\end{array}$ & Brem H & Brem H & 3/12/2002 & 9/25/2003 \\
\hline US 20030165484 & $\begin{array}{l}\text { A method of producing stem cells by incubating differentiated cells with } \\
\text { a processed or activated egg extract and culturing them so that they } \\
\text { dedifferentiate to stem cells; useful for tissue engineering and } \\
\text { wound healing. }\end{array}$ & $\begin{array}{l}\text { TEI Biosciences } \\
\text { (Boston, MA, USA) }\end{array}$ & $\begin{array}{l}\text { Eugene B, } \\
\text { Jianwu D }\end{array}$ & $12 / 4 / 2000$ & 9/4/2003 \\
\hline US 20030162696 & $\begin{array}{l}\text { A functional peptide fiber comprising many peptide structure units, } \\
\text { each containing at least one peptide chain. Peptide chains in each } \\
\text { adjacent peptide structure unit do not form peptide bonds but are } \\
\text { structured into fibrous form by adopting a } \beta \text {-sheet structure; useful } \\
\text { in cell or tissue engineering. }\end{array}$ & $\begin{array}{l}\text { Fuji Xerox Co. Ltd. } \\
\text { (Tokyo) }\end{array}$ & Mihara H & 2/26/2002 & 8/28/2003 \\
\hline US 2003016181 & $\begin{array}{l}\text { A pluripotent embryonic-like stem cell derived from nonembryonic or } \\
\text { postnatal animal cells or tissue, and capable of self-renewal and differ- } \\
\text { entiation to cells of endodermal, ectodermal and mesodermal lineages. }\end{array}$ & $\begin{array}{l}\text { Lucas PA; } \\
\text { Young HE }\end{array}$ & $\begin{array}{l}\text { Lucas PA, } \\
\text { Young HE }\end{array}$ & $3 / 28 / 2001$ & $8 / 28 / 2003$ \\
\hline US 20030119186 & $\begin{array}{l}\text { A protein matrix comprising a fibrin having at least one peptide in a } \\
\text { neurite growth- and extension-promoting amount, where the peptide is } \\
\text { crosslinked to the fibrin; useful for tissue engineering. }\end{array}$ & $\begin{array}{l}\text { Swiss Federal } \\
\text { Institute of } \\
\text { Technology (Zurich) }\end{array}$ & $\begin{array}{l}\text { Hubbell JA, } \\
\text { Sakiyama SE, } \\
\text { Schense JC }\end{array}$ & 8/27/1998 & $6 / 26 / 2003$ \\
\hline US 20030059537 & $\begin{array}{l}\text { A method for attaching a ligand to a surface, comprising contacting the } \\
\text { surface, including an amphiphilic comb polymer, with a substrate having } \\
\text { a ligand; useful in modulating cell-substrate interactions in biomaterials } \\
\text { and tissue engineering, and fabricating multi-analyte biosensors and } \\
\text { genomic arrays. }\end{array}$ & $\begin{array}{l}\text { Chilkoti A; } \\
\text { Hyun J; } \\
\text { Yang Z }\end{array}$ & $\begin{array}{l}\text { Chilkoti A, } \\
\text { Hyun J, } \\
\text { Yang Z }\end{array}$ & $6 / 20 / 2002$ & $3 / 27 / 2003$ \\
\hline US 20020068046 & $\begin{array}{l}\text { The use of fibroblastic cells as stem cells for cell differentiation, } \\
\text { histiogenesis, organogenesis, cell therapy, tissue engineering, and tissue } \\
\text { and organ regeneration. The method comprises exposing the fibroblastic } \\
\text { cells to tissue specific signals to induce the cells to divide, engage in } \\
\text { morphogenesis, differentiate into phenotypes unlike that of the dermal } \\
\text { fibroblast, and/or form tissues and/or organs. }\end{array}$ & $\begin{array}{l}\text { Bell E; } \\
\text { Dai J }\end{array}$ & $\begin{array}{l}\text { Bell E, } \\
\text { Dai J }\end{array}$ & $7 / 9 / 2001$ & $6 / 6 / 2002$ \\
\hline
\end{tabular}

Source: Derwent Information, Alexandria, VA. The status of each application is slightly different from country to country. For further details, contact Derwent Information, 1725 Duke Street, Suite 250, Alexandria, Va 22314. Tel: 1 (800) DERWENT (info@derwent.com). 